Acta Botanica Brasilica - 35(4): 707-713. October-December 2021. doi: 10.1590/0102-33062020abb0478

\title{
The explosive flowers of Marsypianthes chamaedrys (Lamiaceae) resort to self-pollination and improve reproduction
}

\author{
Thiago Amorim ${ }^{1}$ (D), André Maurício Melo Santos ${ }^{3 *}$ (D), Cibele Cardoso Castro 4 (1) and Ana Virgínia Leite ${ }^{2}$ (1)
}

Received: November 6, 2020

Accepted: June 28, 2021

\begin{abstract}
Explosive pollination includes a rapid release of floral sexual elements that are enclosed in modified petals, and a subsequent contact with pollinators' body. It requires specific groups of visitors in order to assure plant reproduction, thus reproductive success is threatened in species with explosive pollination mechanisms, especially when pollinator activity is uncertain. Autogamy can alleviate such a problem by improving plant reproductive output. Here we investigated the mating strategies of Marsypianthes chamaedrys, a species with an explosive pollen release mechanism and whose medicinal properties are broadly investigated, but no data is available regarding its reproduction. We studied its floral morphology, anthesis, floral visitors and breeding system. Flowers have a bilabiate organization with the reproductive structures housed within a lower, keel-like petal lobe. The species is protandrous and flowers have short life span. Only bees were able to activate the explosive mechanism, while butterflies acted as nectar thieves. Marsypianthes chamaedrys is self-compatible and able to autonomously self-pollinate, likely due to the elongation of the pistil within the keel of unvisited flowers. Marsypianthes chamaedrys likely has a mixed mating system, in which bee pollination and autogamy interplay to improve its reproductive output.
\end{abstract}

Keywords: autogamy, explosive pollination, medicinal plant, protandry, reproductive assurance

Explosive pollination has long fascinated the naturalist Charles Darwin, who named "sensitive" those flowers that rapidly respond to a pollinator visitation (Darwin 1862). This pollination mode has independently evolved in many Angiosperm families, and is achieved by different manners
(Aluri \& Reddi 1995). In subtribe Hyptidinae (Lamiaceae), most species present a keel-like structure formed by the lower median petal lobe that houses the stamens and pistil, and that rapidly flips downwards and backwards, shedding pollen on the ventral side of a pollinator (Brantjes \& De-Vos 1981;

1 Programa de Pós-Graduação em Ecologia e Recursos Naturais, Departamento de Biologia, Universidade Federal do Ceará, 60440-900, Fortaleza, CE, Brazil

2 Departamento de Biologia, Universidade Federal Rural de Pernambuco, 52171-900, Recife, PE, Brazil

3 Universidade Federal de Pernambuco, Centro Acadêmico de Vitória, 55608-680, Vitória de Santo Antão, PE, Brazil

4 Universidade Federal do Agreste de Pernambuco, 55292-272, Garanhuns, PE, Brazil

* Corresponding author: biosantos@yahoo.com.br 
Aluri \& Reddi 1996; see Video S1 in supplementary material for a simulation in Rhaphiodon echinus Shauer, Lamiaceae). Explosive pollination, however, poses a problem because pollen may not achieve conspecific stigmas without the aid of a specialized pollinator, and pollen delivery and receipt usually occur at a single visit (Westerkamp 1997). Under stochastic pollination, such a dilemma can be alleviated by autonomous self-pollination (Barrett \& Harder 2017).

Flowering plants have evolved a plethora of reproductive strategies that encourage outcrossing, selfing or a mixed mating system (Barrett \& Harder 2017). Temporal (dichogamy) and spatial (herkogamy) separation of female and male functions can facilitate cross-pollination when protandrous flowers present their pollen before stigma is receptive (Çetinbaş \& Ünal 2014), and by reducing physical interference of stamens and pistils in single hermaphrodite flowers (Barrett \& Harder 2017). Also, many flowering plants make use of self-incompatibility (SI) systems that prevent self-fertilization (Fujii et al. 2016).

Despite being a key-innovation in the evolutionary history of Angiosperms, SI can be lost and enable selfcompatible (SC) plants to reproduce with their own pollen (Fujii et al. 2016). Pollinators can deliver self-pollen on stigmas while visiting a single flower or many flowers of the same plant (Barrett \& Harder 2017). Moreover, self-compatibility can set the stage for the evolution of autonomous self-pollination mechanisms, which do not rely on pollinators for reproduction (Barrett \& Harder 2017). In old, unvisited, but receptive flowers, the reproductive organs can have their position changed in such a way that pollen is eventually self-deposited onto stigmas, resulting in self-fertilization (Toräng et al. 2017). Self-compatible plants, especially those with autonomous self-pollination, tend to produce less pollen grains when compared to SI plants, leading to a low pollen-ovule ratio (Cruden 1977; Pellmyr et at. 2020). Therefore, the evolution of autonomous self-pollination mechanisms can lead plants to reproductive assurance (Toräng et al. 2017), which seems to be advantageous for plants with explosive pollen release.

Here we investigated the reproductive strategies of the annual herb Marsypianthes chamaedrys (Vahl) Kuntze (Lamiaceae; Ocimoideae; Hyptidinae), which exhibits an explosive pollen release mechanism. Marsypianthes chamaedrys is native to Central and South America, and is found in all Brazilian biomes as ruderals (Hashimoto 2013). The species is a popular medicinal plant (Coelho et al. 2020), whose chemical components have shown anti-inflammatory and anti-coagulant actions against snakebites (Magalhães et al. 2011). To our knowledge, there is no data on pollination biology of $M$. chamaedrys, and it offers an opportunity to better understand the reproductive strategies in plants with explosive pollination mechanisms. We studied its floral morphology, anthesis period (including morphometric analysis of the change in size of reproductive organs during the course of anthesis), breeding system, and observed its main visitors and their visiting behaviour in the wild. We also conducted mating system experiments to test selfcompatibility and pollinator-dependency in $M$. chamaedrys.

We studied two populations, the first located at Parque

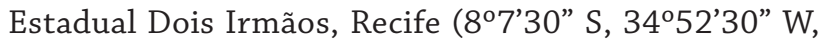
hereafter Area 1), which is one of the largest urban areas of the Atlantic Forest (384.42 ha) in Pernambuco State (Coutinho et al. 1998). The second population is located $28 \mathrm{~km}$ away from Area 1, at Engenho do Paú, a rural area of the municipality of Moreno, Pernambuco State ( $8^{\circ} 7^{\prime} 4^{\prime \prime}$ S, 355'35" W, hereafter Area 2).

For the following procedures, we studied buds and flowers from 20 individuals chosen haphazardly at Area 1. During five consecutive sunny days, we counted the number of flowers opened daily in ten randomly selected inflorescences (one inflorescence per individual). Within those ten inflorescences, we randomly selected 25 flowers and recorded flower longevity. We determined stigma receptivity with a $25 \%$ solution of potassium permanganate (KMnO4) (Robinsohn 1924) at 08:00 h (beginning of anthesis) and at 10:00 h (middle of anthesis), using different sets of 10 flowers for each time (one flower per individual). With the aid of a digital calliper (accuracy $0.01 \mathrm{~mm}$ ), we measured the lengths of the calyx and corolla in two flowers from 15 individuals, totalizing 30 flowers. To determine any change in the size of stamens and pistil throughout the anthesis, we measured their length at 07:00 $\mathrm{h}$ (the beginning of anthesis), at 10:00 $\mathrm{h}$, and at 12:00 $\mathrm{h}$ (the end of anthesis) by using 6 flowers each period (total of 18 flowers from different individuals). In the laboratory, we dissected 30 floral buds under a stereomicroscope to determine the number of pollen grains. Since the flowers have a didynamous arrangement of the androecium (see below), we counted pollen from the upper and the lower stamens. We also counted the number of ovules from the same 30 flowers. Pollen viability was determined for those 30 flower buds with 2\% acetic carmine (Dafni et al. 2005). Pollen ovule (P:O) ratio was calculated after Cruden (1977).

We observed flower visitors at Area 1 (16 hours) and Area 2 (40 hours) on six non-consecutive sunny days. Each day, we observed one focal clump of $M$. chamaedrys from $07: 00 \mathrm{~h}$ to 15:00 $\mathrm{h}$ and recorded the time, the number of visits for each visitor, the number of flowers visited by each floral visitor. We paid special attention to the floral handling behaviour of the visitors: (1) the type of flower visited (unexploded vs. exploded); (2) their ability to activate floral explosion; (3) the main floral reward collected; and (4) contact with stamens and stigma at once. Floral visitors were posteriorly identified to the specific level by a specialist. At Area 1 , we also bagged two flowers at pre-anthesis from 20 individuals and observed them until flower senescence to determine whether the explosive mechanism could be spontaneously activated.

At Area 1, we studied the mating system of M. chamaedrys through the following pollination experiments: (1) hand crosspollination (manual deposition of outcross pollen collected from different plants $50 \mathrm{~m}$ apart); (2) hand self-pollination 
(manual deposition of self-pollen from the same flower); (3) autonomous self-pollination (flowers left intact and bagged), (4) pollinator efficiency (flowers emasculated at pre-anthesis stage and left open for visitation), (5) agamospermy (flowers emasculated at pre-anthesis stage and bagged); and (6) natural pollination (Dafni et al. 2005). We analyzed 100 flowers for the natural pollination experiment and 50 flowers for the remaining treatments. We recorded fruit and seed set for all experiments. We used seed set (seeds/flower) to determine the index of self-incompatibility according to Zapata \& Arroyo 1978. We also determined the index of autofertility, index of autogamous-driven reproductive assurance, and indices of outcross and self pollen limitation following Eckert et al. (2010).

We used generalized linear models (GLMs) with a gaussian distribution to compare stamen length, pollen production and pollen viability (response variables) between the stamen types (predictor variable). For pollen viability, values were square-root arcsine transformed to fulfil the assumptions of normality. The change in size of stamens and pistil during the course of anthesis was analyzed with a one-way ANOVA for each structure. Values were logtransformed to fulfil the assumptions of normality.

We calculated the total number of visits in a single clump at one-hour intervals and used circular statistics to analyze the daily peak of visitors' activity (hereafter, peak of visitation). We removed one unidentified bee species from the analyses due to the small sample size, while the four butterfly species were merged into a single category (butterflies). We calculated the Rayleigh statistics to test for a unimodal frequency distribution. We also calculated the circular mean, and divided its value by 15 to determine the time of the mean peak of visitation. We then calculated the mean resultant length (Rho) as a concentration parameter of the frequency distribution. Values close to 1 indicate that the peak of visitation is more concentrated on a given period, other than overdispersed throughout our observation period $(07: 00 \mathrm{~h}-15: 00 \mathrm{~h})$. Finally, we used a circular ANOVA to compare the mean peak of visitation between visitors.

We calculated total number of flowers visited by each visitor, and used a generalized linear mixed model (GLMM) with the study area as a random factor and a Poison distribution to compare the number of visited flowers by each visitor species. For those tests, we considered the two most frequent bee species (A. mellifera and Paratetrapedia sp.), while the lepidopteran species were merged into a single category (butterflies; see Tab. S1 for details of visitor species). For the following tests, we analyzed data from Area 1 and 2, and split the visitors into two categories (bees vs. butterflies). We used the log likelihood ratio (G-test) to determine whether bees and butterflies differ in their frequency of visitation to unexploded and exploded flowers. To determine which type of visitor (bees or butterflies) is able to activate the explosive mechanism of the flowers, we used the Fisher's exact test. This test was used due to the low sample size for the butterflies.
To determine whether the pollination experiment (predictor variable) account for seed set (response variable), we used a GLM with a quasipoisson family and Tukey's HSD posthoc test to analyze seed set. In addition, we used the function anova.glm of the stats-package (R Development Core Team 2019) to produce an analysis of variance table from the model. Fruit set was analyzed with a goodness of fit chi-square test. All analyses were carried out in R ( R Development Core Team 2019).

In $M$. chamaedrys, the pedunculate monochasial inflorescences bear $1.2 \pm 0.5$ opened flowers a day. The calyx is synsepalous, cup-shaped and $4.60 \pm 0.49 \mathrm{~mm}$ in length. The corolla is violet, tubular, bilabiate and $6.93 \pm 0.90 \mathrm{~mm}$ in length. The upper lip shows two upright petal lobes, while the lower lip has two downwardly lateral lobes and a median lowermost one. This median lobe is turned into a keel-like structure that houses the distal portion of the stamens and pistil (Fig. 1A). There are four stamens whose filaments are mostly fused to the lower lip of tubular corolla (forming a stapet), but free distally (Fig. 1B). The stamens are in a didynamous arrangement, with two shorter and in a lower position, while the remaining two are longer and in an upper position $\left(F_{1,56}=85.957 ; P<0.001\right)$. In both sets of stamens, the anthers are dorsifixed and longitudinally dehiscent. The upper and lower stamens produce $40.90 \pm 27.43$ and 41.67 \pm 25.05 pollen grains, and the number of pollen grains did not differ between them $\left(F_{1,58}=0.082 ; P=0.77\right)$. Pollen viability was $99.8 \%$ and $97.9 \%$ for upper and lower stamens, respectively, and did not differ between the stamen sets $\left(F_{1,50}\right.$ $=0.28 ; P=0.60)$. $\mathrm{P}: \mathrm{O}$ ratio was 20.5 . The pistil is $4.56 \pm 0.84$ $\mathrm{cm}$ in length and is positioned in the midline of the lower lip, between the two sets of stamens. At its base there is a superior, bicarpellary ovary of $0.67 \pm 0.09 \mathrm{~cm}$ in length (with two ovules per locule), surrounded by a nectariferous disk.

Most flowers opened at around 07:00 $\mathrm{h}$ and lasted for up to four hours. At the beginning of anthesis, flowers were under tension and the explosive mechanism could be activated. Flowers entered the male phase first, with all dehiscing anthers presenting their pollen inside the keel. Marsypianthes chamaedrys is, therefore, protandrous. Approximately two hours later, the two arms of the bifid stigma curled down and became receptive so that the flower entered the hermaphrodite phase. The size of the pistil changed during the course of anthesis $\left(F_{2,15}=672.5 ; P=0.002\right.$; Fig. 2$)$. The pistil extended significantly between $07: 00 \mathrm{~h}$ and $10: 00 \mathrm{~h}$ ( $P=0.006)$ and between $07: 00 \mathrm{~h}$ and $12: 00 \mathrm{~h}(P=0.003)$, but no difference was observed between 10:00 $\mathrm{h}$ and 12:00 $\mathrm{h}(P$ $=0.936 ;$ Fig. $2 \mathrm{~A}$ ). Thus, the pistil became more exerted in the median plane of the lower lip, between the two lateral lobes. We did not find a significant change in the size of the upper $\left(F_{2}\right.$, $\left.{ }_{15}=16.6 ; P=0.834\right)$ and lower $\left(F_{2,15}=1.45 ; P=0.45\right)$ stamens during the anthesis (Fig. $2 B$ and $C$ ). In five flowers (12.5\%), the explosive mechanism was spontaneously activated, and the pollen was launched towards the internal side of the upper lip, where the grains were held by the internal petal hairs. 

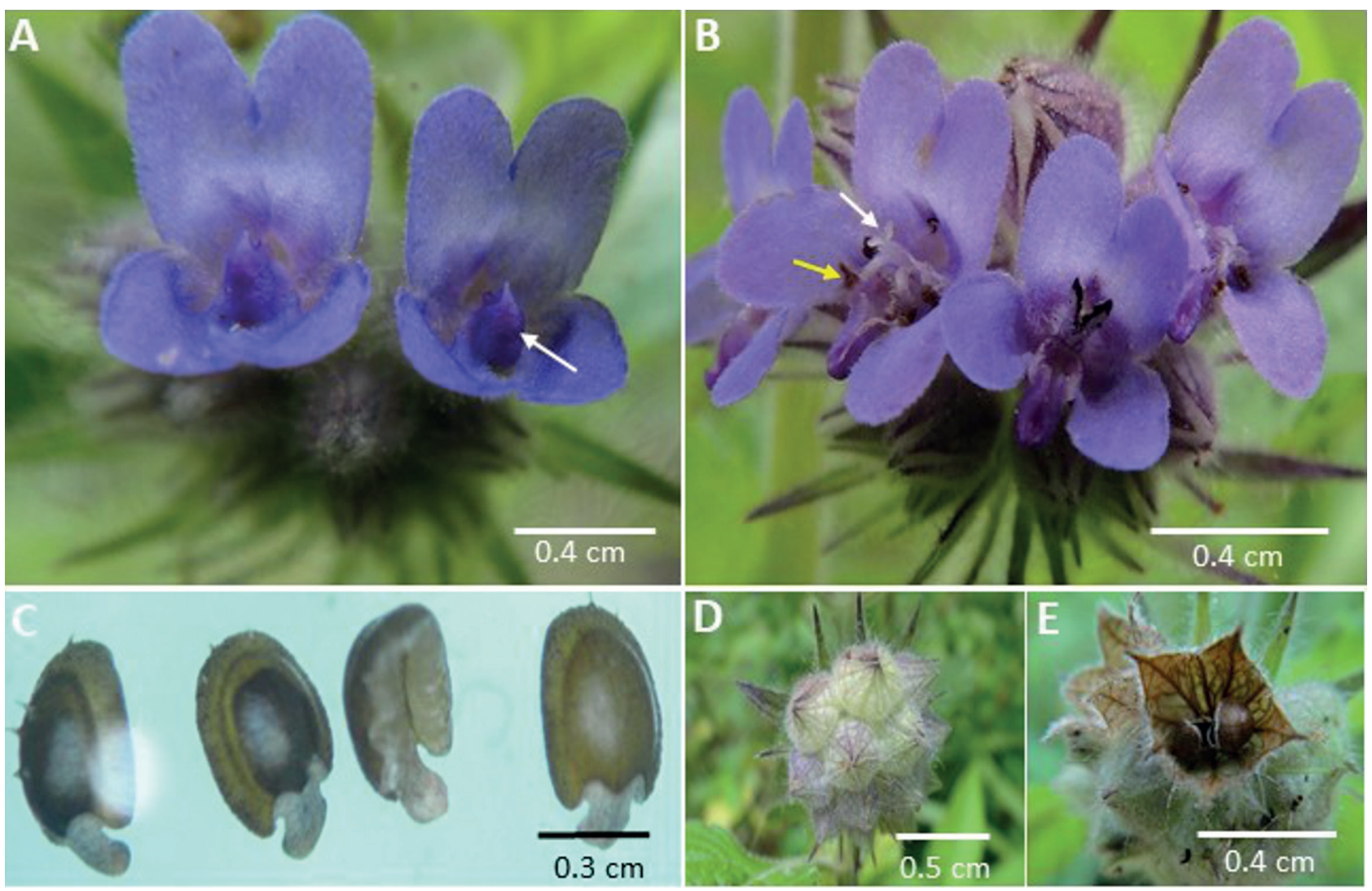

Figure 1. Flowers and fruits of Marsypianthes chamaedrys at Parque Estadual Dois Irmãos, Recife, Pernambuco State, NE Brazil. A: unexploded flowers (white arrow shows the keel-like structure housing the reproductive structures; B: exploded flowers (white and yellow arrows show the bifid stigma and an anther, respectively); C: fruit details; D: fruits enclosed within the sepals; E: fruits at dispersion phase.

At Area 1, we recorded visits by the bee Apis mellifera (Linnaeus 1758), by one unidentified bee (Apidae sp. 1), and by the butterfly Vehilius stictomenes stictomenes (Butler 1877). At Area 2, we recorded visits by the bees A. mellifera and Paratetrapedia sp., and by three butterfly species (see Tab. S1 in supplementary material). Overall, visits started between 08:00 $\mathrm{h}$ and 09:00 $\mathrm{h}$ and extended up to approximately 13:30 h. At Area 1, A. mellifera showed a unimodal frequency (Rayleigh's test $=0.952 ; P<0.001$ ), a peak of visitation at around $10: 45 \mathrm{~h}$, and a more concentrated pattern of visitation (Rho $=0.952)$. At Area 2, we found a unimodal frequency of visitation for A. mellifera (Rayleigh's test $=0.948 ; P<0.001$ ), Paratetrapedia sp. (Rayleigh's test $=0.995 ; P<0.001$ ) and butterflies (Rayleigh's test $=0.979$; $P<0.001)$. Apis mellifera showed a mean peak of visitation at 10:00 h, while mean peak of visitation for Paratetrapedia sp. and butterflies occurred at 09:00 h (Fig. 3). The three types of visitors showed a concentrated visitation pattern (A. mellifera, $\mathrm{Rho}=0.943 ;$ Paratetrapedia sp., $\mathrm{Rho}=0.995$; butterflies, Rho $=0.977)$. We found no difference in the time of the mean peak of visitation between $A$. mellifera and Paratetrapedia sp. $\left(F_{1,25}=3.846 ; P=0.06\right)$ and A. mellifera and butterflies $\left(F_{1,28}=3.575 ; P=0.06\right)$, nor between Paratetrapedia sp. and butterflies $\left(F_{1,14}=0.187 ; P=0.67\right)$.
At Area 1, A. mellifera and the butterflies visited $1.65 \pm$ 0.22 and $2.5 \pm 1.5$ flowers, respectively, per foraging bout (mean \pm standard error). At Area 2, A. mellifera, Paratetrapedia sp., and the butterflies visited, respectively, $2.37 \pm 0.32,1.67$ \pm 0.33 , and $1.57 \pm 0.30$ flowers, per foraging bout, and there was no difference among those values $\left(\chi^{2}=0.56 ; \mathrm{df}=2 ; P=\right.$ 0.76). At Area 1, bees and butterflies visited exploded and unexploded flowers at similar frequencies $(G=0.74 ; \mathrm{df}=1 ; P$ $=0.39$ ). At Area 2 , bees visited more frequently unexploded flowers, while butterflies visited more frequently exploded flowers $(G=5.39 ; \mathrm{df}=1 ; P=0.02)$. However, when visiting intact flowers, only bees activated the explosive mechanism at Area 1 and Area 2 (Fisher's exact test: $P<0.001$ ). The bees landed on the lower flower lip and, while probing for nectar at the base of the flower tube, the keel-lobe flipped backwards violently, the four didynamous stamens moved upwards and shed pollen on the ventral side of the bees, the same area contacted by the stigma. With the impact, pollen can be almost totally removed in a single visit (see Video S1 in supplementary material). When visiting exploded flowers, the ventral part of the bees touched the stigma. The butterflies were considered nectar thieves, since they landed on the lower flower lip, introduced only their proboscis into the flower tube and sucked nectar without activating the explosive mechanism or touching any floral reproductive organ. 


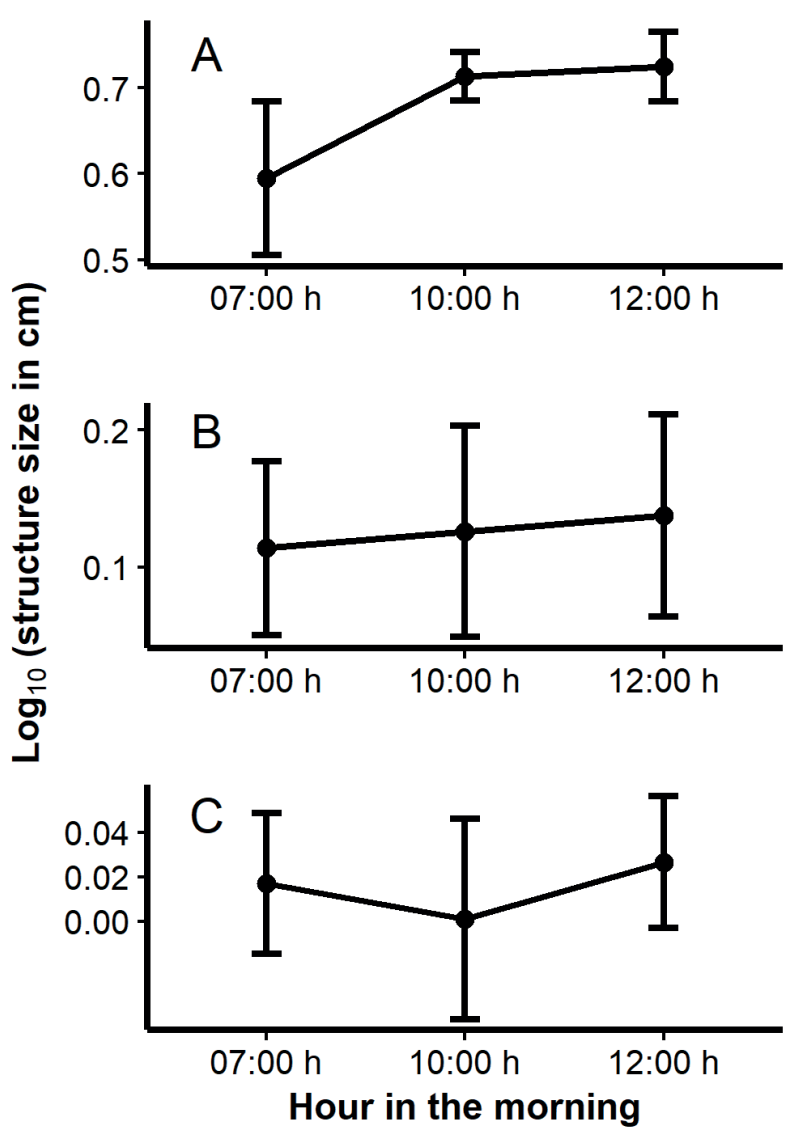

Figure 2. Change in size of pistil (A) lower (B) and upper (C) stamens of Marsypianthes chamaedrys (Lamiaceae) in an area of Atlantic Forest of NE Brazil, at 07:00 h, 10:00 h and 12:00 h.
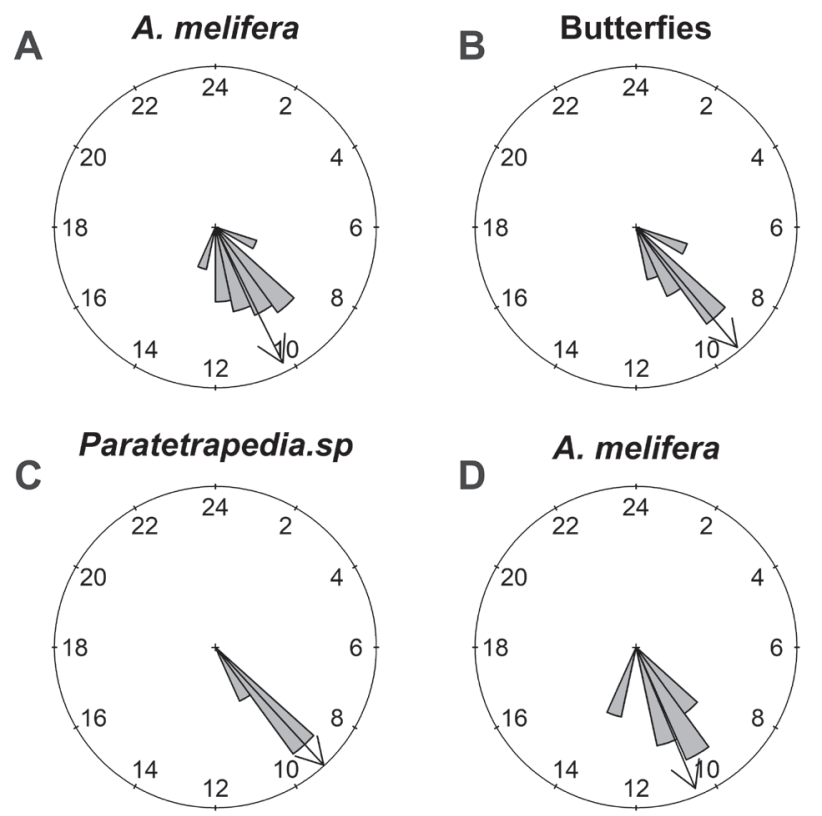

Figure 3. Circular histograms showing the peak of visitation along the observation period of A. mellifera (A), Paratetrapedia sp. (B) and butterflies (C) at Area 2, and A. mellifera (D) at Area 1. The direction of vectors points towards the mean peak of visitation.
Individuals of $M$. chamaedrys set fruits and seeds in all pollination experiments, except after agamospermy treatment (Fig. 4). Fruit set differed among pollination experiments $\left(\chi^{2}=209.62 ; \mathrm{df}=5 ; P<0.001\right)$. There was a $100 \%$ fruit set under natural pollination and autonomous self-pollination compared with $88 \%, 66 \%$ and $44 \%$ in the hand self-pollination, hand cross-pollination and pollinator efficiency treatments, respectively (Fig. 4A). After successful pollination, the calyx remains closed around one to four seeds, and opens during dispersion phase (Fig. 1C - E). Seed set also differed among the pollination experiments $\left(F_{1,4}=2.4197 ; P=0.049\right)$. However, this difference occurred only between the autonomous self-pollination and the hand self-pollination treatments, with no differences among the remaining treatments. The autonomous selfpollination treatment produced more seeds than the hand self-pollination treatment $(P=0.048$; Fig. 4B). Marsypianthes chamaedrys is self-compatible (ISI $=-0.28$ ) and autofertile $(\mathrm{IAF}=1.28)$. We found a moderate degree of autogamousdriven reproductive assurance $(\mathrm{RA}=0.46)$. We did not find evidence for outcross $\left(\mathrm{PL}_{\mathrm{x}}=-0.31\right)$ and self $\left(\mathrm{PL}_{\mathrm{s}}=-0.16\right)$ pollen limitation in M. chamaedrys.
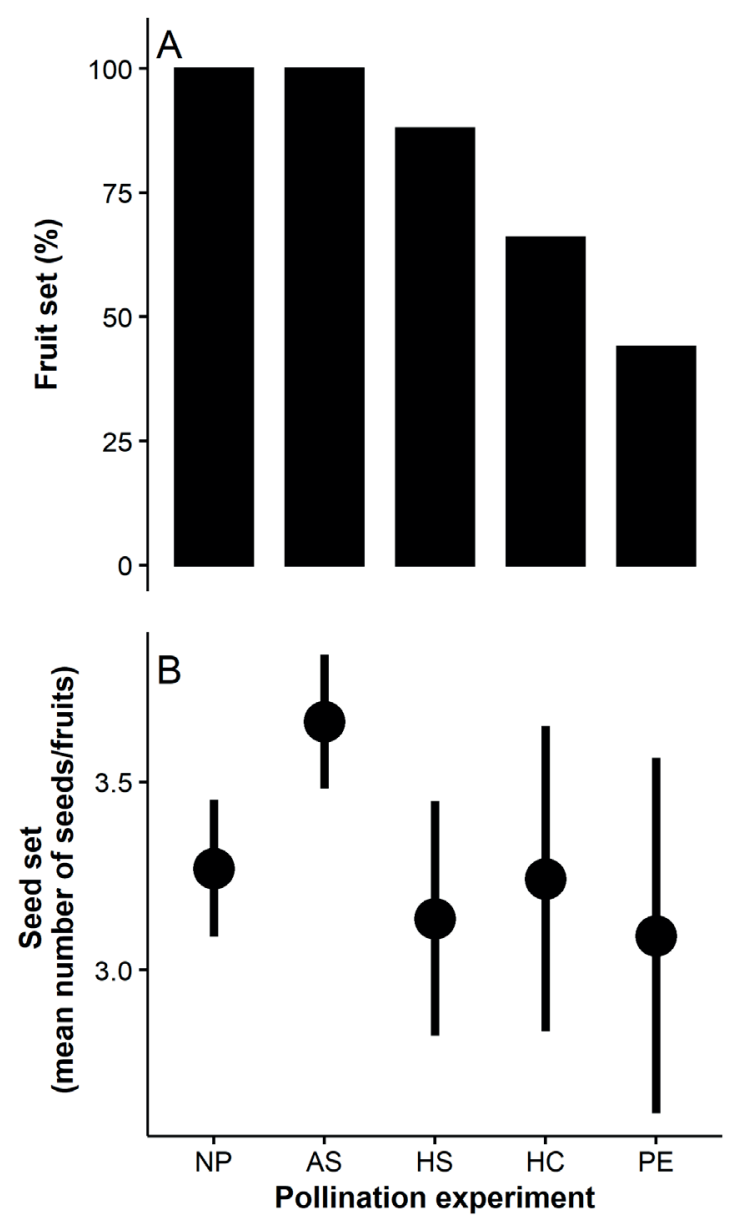

Figure 4. Pollination experiments with Marsypianthes chamaedrys (Lamiaceae) in an area of Atlantic Forest of NE Brazil. A: fruit set; B: seed set. NP: natural pollination, AS: autogamous self-pollination; HS: hand self-pollination; HC: hand cross-pollination; PE: pollinator efficiency. 
We showed that bees are the most effective pollinators, since they activated the explosive mechanism and touched all reproductive structures at a visit. In fact, the floral traits of M. chamaedrys fit the melittophilous syndrome (Westerkamp \& Claßen-Bockhoff 2007). Although subtribe Hyptidinae is native to the Americas (Pastore et al. 2011), the exotic A. mellifera seems to be an effective pollinator of $M$. chamaedrys, which may indicate competitive exclusion or local extinction of the native pollinator. Hyptidinae species have been introduced in the Old World, where they have spread as weeds, possibly with the extinction of native pollinators and through selfing (e.g., Hyptis suaveolens (L.); Aluri 1990). Butterflies acted as nectar thieves, were unable to activate the explosive mechanism, and did not touch the reproductive organs. However, bees are likely unable to assess if nectar was depleted by butterflies, and land on those flowers, eventually effecting pollination.

Marsypianthes chamaedrys has specialized flowers, adapted to bee pollination through an explosive pollen release mechanism. In the family Lamiaceae, most flowers have their reproductive organs underneath the upper lip and promote a nototribic pollen deposition (Harley et al. 2004). Many of those species have sophisticated pollination modes, such as the lever mechanism in Salvia (Claßen-Bockhoff et al. 2004). Marsypianthes chamaedrys follows the typical floral morphology found in subtribe Hyptidinae: (1) the upper lip is split into two petal lobes; (2) the lower lip is divided into three lobes, with the median one forming a keel-like structure that encloses the reproductive organs; (3) the complex stamens-pistil-keel is constantly under pressure at anthesis; (4) when a pollinator inserts its mouthparts, the keel rapidly reflexes downwards and backwards; and (5) the filaments violently swing up and shed pollen nototribicaly (on the ventral side of a pollinator; Brantjes \& De Vos 1981; Aluri \& Reddi 1996). The explosive pollination has evolved independently many times in subtribe Hyptidinae (Pastore et al. 2011). In M. chamaedrys, the didynamous arrangement of the stamens with firmly attached anthers is considered to be adapted to support the impact on the pollinator after flower explosion (Brantjes \& De Vos 1981). Elaborated pollination mechanisms often lead to a more precise animal-mediated pollen transfer from anthers to conspecific stigmas (Claßen-Bockhoff et al. 2004). Our natural pollination and pollinator efficiency treatments along with a lack of outcross pollen limitation reveal that the studied population of $M$. chamaedrys receives efficient pollinator service to set fruits and seeds.

Marsypianthes chamaedrys showed traits that favour cross-pollination. The observed protandry allows pollen removal while stigmas are not yet receptive, and cause pollen to be accumulated on the ventral side of bees until being deposited on receptive stigmas. Protandry is a trait spread in the Lamiaceae (Harley et al. 2004), and thus can reduce the likelihood of self-pollination, favouring the outcrossing component of $M$. chamaedrys. The elongation of the pistil during the anthesis, a common phenomenon for the Hyptidinae (Harley et al. 2004), cause the stigma to be more exerted leading to a temporal herkogamy, which is expected to favour cross-pollination (Luo \& Widmer 2013).

On the other hand, M. chamaedrys also showed traits that allow self-pollination. Similar to the great majority of the Lamiaceae (Harley et al. 2004), self-compatibility in $M$. chamaedrys opens the opportunity for autonomous self-pollination, as observed in the pollination experiment. Since bagged flowers remained unexploded, self-deposition of pollen may occur inside the keel in protandrous flowers, and may be facilitated by the later elongation of the pistil. Our results showed that $M$. chamaedrys is not self-pollenlimited, meaning that both sets of stamens provide enough and viable pollen for self-pollination. A moderate level reproductive assurance index further supports the idea that $M$. chamaedrys can use an autonomous self-pollination mechanism to ensure fruit and seed sets when animal pollination is unreliable (Charlesworth 2006). To a lesser extent, spontaneous explosion of flowers may lead to autonomous self-pollination through a secondary pollen presentation, in which pollen grains held by hairs of the upper lip come into contact with the stigma when flowers wilt. However, this possibility is yet to be fully confirmed in future studies.

Marsypianthes chamaedrys has specialized flowers adapted to animal pollination through an explosive pollen release mechanism activated only by bees. Also, M. chamaedrys has traits indicative of outcrossing and selfing strategies. It also indicates that $M$. chamaedrys receives adequate pollinator service, but can make use of an autonomous self-pollination mechanism as reproductive assurance. The breeding system seems to be context dependent (Kalisz et al. 2004) and to have a mixed mating strategy. If, on the one hand, cross pollination provides genetic variability, on the other hand, selfing promotes reproductive assurance and genotype preservation of pure lineages (Charlesworth 2006), especially demanded in commercial crops (Yan et al. 2017). Future studies measuring outcrossing rates could shed light on the extent to which $M$. chamaedrys shows a mixed mating system.

\section{Acknowledgements}

We thank Dois Irmãos State Park and the Laboratório de Ecologia Reprodutiva de Angiospermas (Universidade Federal Rural de Pernambuco) for allowing field and laboratory work, respectively. We also thank Carlos Nobre for visitors' identification.

\section{References}

Aluri RJS. 1990. The explosive pollination mechanism and mating system of weedy Hyptis suaveolens (Lamiaceae). Plant Species Biology 5: 235-241. 
Aluri RJS, Reddi CS. 1995. Explosive pollen release and pollination in flowering plants. Proceedings of the Indian National Science Academy B 61: 323-332.

Aluri RJS, Reddi CS. 1996. The explosive floral-mechanism and pollination in the genus Hyptis (Lamiaceae). Proceedings of the Indian National Science Academy B 62: 117-124.

Barrett SCH, Harder LD. 2017. The ecology of mating and its evolutionary consequences in seed plants. Annual Review of Ecology, Evolution, and Systematics 48: 135-157.

Brantjes NBM, De Vos OC. 1981. The explosive release of pollen in flowers of Hyptis (Lamiaceae). New Phytologist 87: 425-430.

Çetinbaş A, Ünal M. 2014. An overview of dichogamy in angiosperms. Research in Plant Biology 4: 9-27.

Charlesworth D. 2006. Evolution of plant breeding systems. Current Biology 16: 726-735.

Claßen-Bockhoff R, Speck T, Tweraser E, Wester P, Thimm S, Reith M. 2004. The staminal lever mechanism in Salvia L. (Lamiaceae): a key innovation for adaptive radiation? Organisms Diversity and Evolution 4:189-205.

Coelho MN, Soares PAG, Frattani FS, et al 2020. Polysaccharide composition of an anticoagulant fraction from the aqueous extract of Marsypianthes chamaedrys (Lamiaceae). International Journal of Biological Macromolecules 145: 668-681.

Coutinho R, Lima-Filho M, Souza-Neto J, Silva E. 1998. Características climáticas, geológicas, geomorfológicas e geotécnicas da Reserva Ecológica de Dois Irmãos. Reserva Ecológica de Dois Irmãos: Estudos em um remanescente de Mata Atlântica em área urbana (RecifePernambuco-Brasil). Recife, Editora Universitária da UFPE.

Cruden RW. 1977. Pollen-Ovule Ratios: A conservative indicator of breeding systems in flowering plants. Evolution 31: 32-46.

Dafni A, Kevan PG, Husband BC. 2005. Practical Pollination Biology. Ontario, Enviroquest, Cambridge.

Darwin C. 1862. On the various contrivances by which British and foreign orchids are fertilised by insects, and on the good effects of intercrossing. Cambridge, Cambridge University Press.

Eckert CG, Kalisz S, Geber MA, eta al. 2010. Plant mating systems in a changing world. Trends in Ecology and Evolution 25: 35-43.

Fujii S, Kubo KI, Takayama S. 2016. Non-self- and self-recognition models in plant self-incompatibility. Nature Plants 2: 1-9.

Harley RM, Atkins S, Budantsev AL, et al. 2004. Labiatae. In: Kadereit JW. (ed.) Flowering Plants - Dicotyledons. Berlin, Springer. p. 167-275.
Hashimoto MY. 2013. Estudos taxonômicos do gênero Marsypianthes Mart. ex Benth. (Hyptidinae, Lamiaceae) no Brasil. MSc Thesis, Universidade Federal de Goiás, Goiânia.

Kalisz S, Vogler DW, Hanley KM. 2004. Context-dependent autonomous self-fertilization yields reproductive assurance and mixed mating. Nature 430: 884-887.

Luo Y, Widmer A. 2013. Herkogamy and its effects on mating patterns in Arabidopsis thaliana. PLOS ONE 8: e57902. doi: 10.1371/journal. pone.0057902

Magalhães A, Santos GB, Verdam MCDS, et al. 2011. Inhibition of the inflammatory and coagulant action of Bothrops atrox venom by the plant species Marsypianthes chamaedrys. Journal of Ethnopharmacology 134: 82-88.

Pastore JFB, Harley RM, Forest F, Paton A, Berg C. 2011. Phylogeny of the subtribe Hyptidinae (Lamiaceae tribe Ocimeae) as inferred from nuclear and plastid DNA. Taxon 60: 1317-1329.

Pellmyr O, Kjellberg F, Herre EA, Kawakita A, Hembry DH, Holland JN, Terrazas T, Clement W, Segraves KA, Althoff DM. 2020. Active pollination drives selection for reduced pollen-ovule ratios. American Journal of Botany 107: 164-170.

R Development Core Team. 2019. R: a language and environment for statistical computing. R Foundation for Statistical Computing, Vienna, Austria. https://www.r-project.org/. 3 March 2019.

Robinsohn I. 1924. Die Färbungsreaktion der Narbe, stigmatochromie, als morpho-biologische Blütenuntersuchungsmethode. Sitzungsberichte der Kaiserlichen Akademie der Wissenschaften MathematischNaturwissenschaftliche Classe Abteilung 1: 181-211.

Toräng P, Vikström L, Wunder J, Wötzel S, Coupland G, Ågren J. 2017. Evolution of the selfing syndrome: anther orientation and herkogamy together determine reproductive assurance in a self-compatible plant. Evolution 71: 2206-2218.

Westerkamp C. 1997. Keel blossoms: bee flowers with adaptations against bees. Flora 192: 125-132.

Westerkamp C, Claßen-Bockhoff R. 2007. Bilabiate flowers: the ultimate response to bees? Annals of Botany 100: 361-374.

Yan G, Liu H, Wang H, Lu Z, Wang Y, Mullan D, Hamblin J, Liu C. 2017. Accelerated generation of selfed pure line plants for gene identification and crop breeding. Frontiers in Plant Science 8: 1786. doi: 10.3389/ fpls.2017.01786

Zapata TR, Arroyo MTK. 1978. Plant reproductive ecology of a secondary deciduous tropical forest in Venezuela. Biotropica 10: 221-230. 